Preparat ory St udy for the Synt hesi s of the Nar i ne Sponge Al kal oi ds Asmari nes A-F: Synthesi s of Thei $r$ Het er ocycl i c Porti ons

\begin{tabular}{|l|l|}
\hline 著者 & Ohba Masashi , Tashi ro Takahi ro \\
\hline $\begin{array}{l}\text { j our nal or } \\
\text { publ i cat i on ti t l e }\end{array}$ & Het er ocycl es \\
\hline vol une & 57 \\
\hline nunber & 7 \\
\hline page $\mathrm{r}$ ange & $1235-1238$ \\
\hline year & 2002- 01- 01 \\
\hline URL & ht t p: //hdl . handl e. net /2297/3276 \\
\hline
\end{tabular}




\title{
PREPARATORY STUDY FOR THE SYNTHESIS OF THE MARINE SPONGE ALKALOIDS ASMARINES A-F: SYNTHESIS OF THEIR HETEROCYCLIC PORTIONS
}

Masashi Ohba ${ }^{a, *}$ and Takahiro Tashiro ${ }^{b}$

aCenter for Instrumental Analysis, Kanazawa University, Takara-machi, Kanazawa 920-0934, Japan

baculty of Pharmaceutical Sciences, Kanazawa University, Takara-machi, Kanazawa 920-0934, Japan

\begin{abstract}
A synthesis of three tricyclic compounds (1c), (2c), and (3c), selected as models for the heterocyclic portions of the marine sponge alkaloids asmarines A-F, has been accomplished through cyclization of the 7-alkyl-6-chloropurine derivatives.
\end{abstract}

Asmarines A (1a) and B (1b), novel purine-related alkaloids ${ }^{1}$ isolated from the Red Sea sponge Raspailia sp., display significant cytotoxicity against four human cancer cell lines. ${ }^{2}$ The same sponge is further known to contain four closely related alkaloids, i.e., asmarines $\mathrm{C}(2 \mathrm{~b}), \mathrm{D}(2 \mathrm{a}), \mathrm{E}(3 \mathrm{a})$, and $\mathrm{F}(3 \mathrm{~b})$, although none of them have been isolated in pure forms. ${ }^{2 b}$ The structures of these alkaloids were elucidated through extensive spectral studies in conjunction with an X-Ray crystallographic analysis of asmarine A (1a). ${ }^{2 a}$ In connection with our ongoing interest in the synthetic study of purine alkaloids, ${ }^{3}$ we sought possible synthetic routes to the heterocyclic models $(\mathbb{1} \mathfrak{c}),(2 \mathfrak{c})$, and $(3 \mathfrak{c})$ possessing a $[1,4]$ diazepino[1,2,3$g h$ ]purine skeleton as a preliminary to the total synthesis of asmarines A-F.

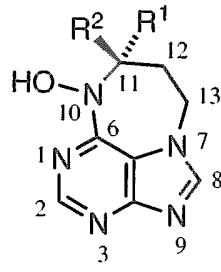

1

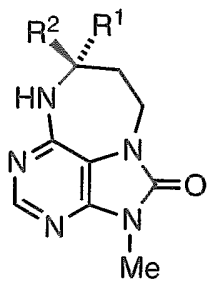

2<smiles>[R]C1([R])CCn2c(=O)n(C)c3ncnc(c32)N1OC</smiles>

3

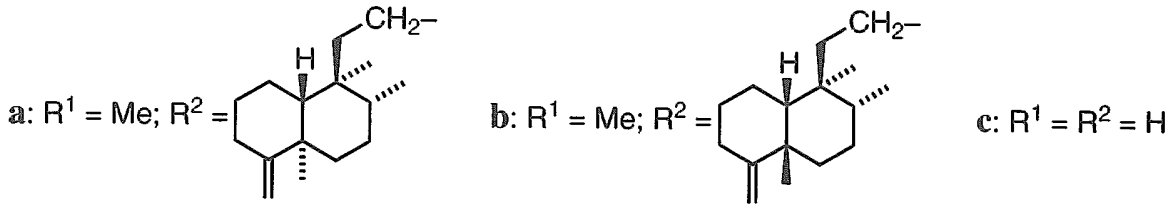


The synthesis of the tricyclic hydroxylamine (1c), selected as a model for a common heterocyclic portion of asmarines $\mathrm{A}$ and $\mathrm{B}$, was first investigated. Kashman and co-workers have recently reported the construction of a $[1,4]$ diazepino[1,2,3-gh]purine system via intramolecular alkylation at the $N^{6}$-position of 9benzyl- $N^{6}$-benzyloxy-7-(3-chloropropyl)adeninium salt without description of the removal of two benzyl groups. ${ }^{4}$ Toward the development of a route applicable to the synthesis of asmarines, we envisioned that intramolecular amination at the 6-position of an appropriate 7-(3-hydroxyaminopropyl)-6-chloropurine (5) (route b) would be preferable to cyclization at the $N^{6}$-position of the adenine derivative (4) (route a), because the latter route is presumed to be more difficult in constructing the stereogenic center at the 11position of asmarines. At the outset of the present synthesis, therefore, we needed the 7-alkylated 6chloropurine $(5) .5^{5}$

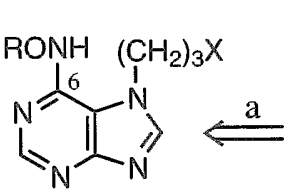

4

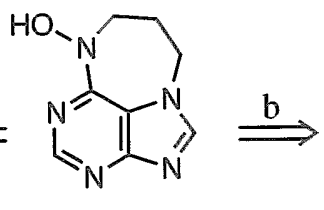

$1 c$<smiles>Cn1cnc2ncnc(Cl)c21</smiles>

5

Since direct alkylation of 6-chloropurine using alkyl halide and a base ${ }^{6}$ or under Mitsunobu conditions ${ }^{7}$ has been reported to occur at the 9-position predominantly over the 7-position, we investigated an alternative route via cyclization of pyrimidine derivative to obtain the requisite purine (5). On treatment of the formamide (6) in DMF with the bromide (7) $\left(\mathrm{K}_{2} \mathrm{CO}_{3}, \mathrm{Bu}_{4} \mathrm{NI}\right.$, room temperature, $\left.24 \mathrm{~h}\right)$ according to a precedent, ${ }^{8}$ the $\mathrm{N}$-alkylated formamide ( 8 ) was obtained in $74 \%$ yield. Subsequent base-promoted cyclization of 8 was very slow in DMF, but proceeded smoothly in 1-BuOH $\left(35-40{ }^{\circ} \mathrm{C}, 2 \mathrm{~h}\right)$ to afford the desired 7 alkylated 6-chloropurine (9) in $87 \%$ yield. Removal of the Alloc group of 9 with Pd catalyst in the presence of 2-ethylhexanoic acid $9\left(\mathrm{CH}_{2} \mathrm{Cl}_{2}-\mathrm{Et}_{2} \mathrm{O}\right.$, room temperature, $\left.1.5 \mathrm{~h}\right)$ and intramolecular amination at the 6-position of the resulting amine using $\mathrm{Et}_{3} \mathrm{~N}(1-\mathrm{BuOH}$, reflux, 2 h) provided the tricyclic compound (10) containing a $[1,4]$ diazepino[1,2,3-gh]purine skeleton in $75 \%$ yield. Finally, deprotection of 10 with concd $\mathrm{HCl}\left(\mathrm{THF}, 55^{\circ} \mathrm{C}, 1.5 \mathrm{~h}\right)$ gave the first target $(1 \mathrm{c})\left(\mathrm{mp} 204-205^{\circ} \mathrm{C}\right){ }^{10}$ in $86 \%$ yield.<smiles>Nc1ncnc(Cl)c1NC=O</smiles>

6

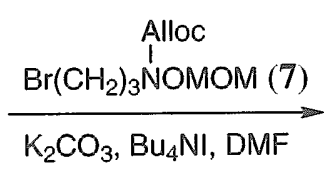

$\mathrm{K}_{2} \mathrm{CO}_{3}, \mathrm{Bu}_{4} \mathrm{NI}, \mathrm{DMF}$

1. $\mathrm{Pd}\left(\mathrm{PPh}_{3}\right)_{4}, \mathrm{PPh}_{3}$ 2-ethylhexanoic acid $\mathrm{CH}_{2} \mathrm{Cl}_{2}-\mathrm{E}_{2} \mathrm{O}$

2. $\mathrm{E}_{3} \mathrm{~N}, 1-\mathrm{BuOH}$

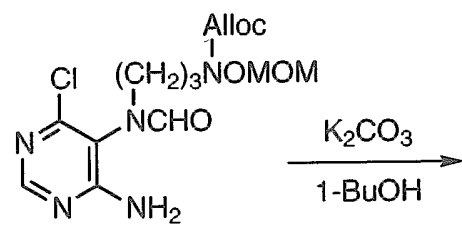

8<smiles></smiles>

9<smiles></smiles>

10<smiles>ON1CCCn2cnc3ncnc1c32</smiles>

10<smiles>COC(=O)N1CCCn2cnc3nc(OC)nc1c32</smiles> 
In connection with the structure elucidation of asmarine $\mathbf{B}(\mathbf{1 b})$, Kashman and co-workers further described the reaction of $\mathbf{1 b}$ with excess acetic anhydride in $\mathrm{MeOH}$ to produce 12 via a four-step mechanism: acetylation of the $\mathrm{NOH}$ group, a [3,3] sigmatropic rearrangement, 1,6-addition of $\mathrm{MeOH}$, and elimination of acetic acid. ${ }^{2 b}$ On treatment with excess acetic anhydride in $\mathrm{MeOH}$ at room temperature for $30 \mathrm{~h}$, the hydroxylamine (1c) also afforded 11 in $71 \%$ yield. Concomitant acetylation at the 10 -position in the latter is probably due to no sterically congested environment compared to $\mathbf{1 2}$, which possesses two substituents at the 11-position.

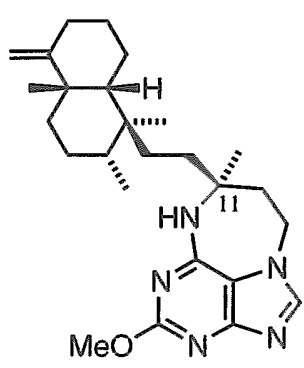

12
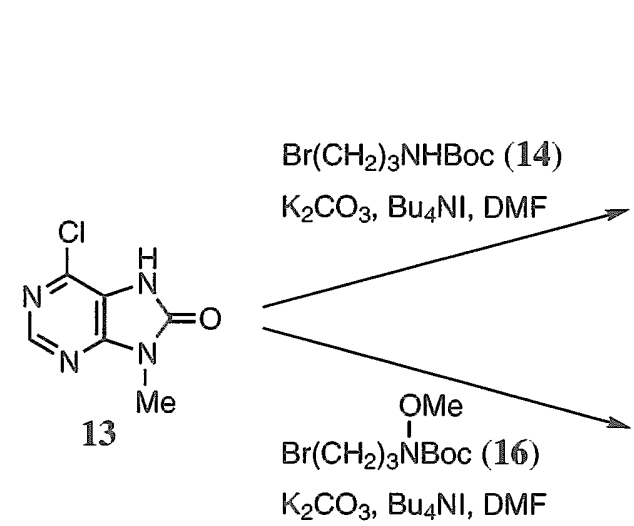<smiles>Cn1c(=O)n(C)c2c(Cl)ncnc21</smiles>

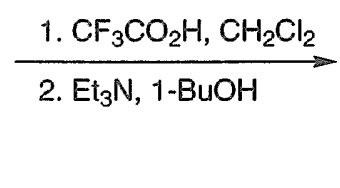<smiles>Cn1c(=O)n2c3c(ncnc31)NCCC2</smiles><smiles>CON(C)C(=O)O[Na]</smiles>

17

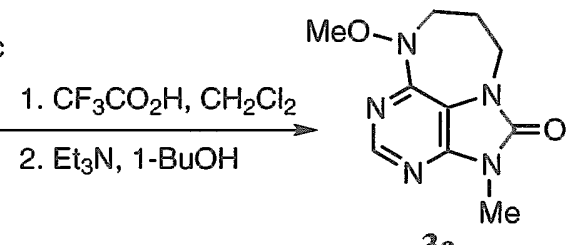

Our attention was next turned to the synthesis of two heterocyclic models $(2 \mathfrak{c})$ and $(3 \mathfrak{c})$ for asmarines $\mathrm{C}$ (2b), D (2a) and asmarines E (3a), F (3b), respectively. Based on the results obtained with 1 c, we selected the 8-oxopurine (13) ${ }^{1,12}$ as a starting material. Alkylation of $\mathbf{1 3}$ with the bromide (14) in DMF $\left(\mathrm{K}_{2} \mathrm{CO}_{3}, \mathrm{Bu} 4 \mathrm{NI}\right.$, room temperature, $22 \mathrm{~h}$ ) proceeded at the 7-position, giving $\mathbf{1 5}$ in $99 \%$ yield. Removal of the Boc group and subsequent cyclization with $\mathrm{Et}_{3} \mathrm{~N}$ (1-BuOH, reflux, $2 \mathrm{~h}$ ) produced the second target (2c) $\left(\mathrm{mp} 286.5-287.5^{\circ} \mathrm{C}\right)$ in $98 \%$ yield. A parallel sequence of reactions starting from 13 and the bromide (16) provided the third target $(3 \mathrm{c})\left(\mathrm{mp} 146-147^{\circ} \mathrm{C}\right.$ ) through 17 in $76 \%$ overall yield. The ${ }^{1} \mathrm{H}$ - and ${ }^{13} \mathrm{C}$ NMR spectral signals of the model compounds $(\mathbf{1 c}),(2 \mathfrak{c})$, and $(3 \mathfrak{c})$ thus synthesized were similar, except for those affected by two substituents at the 11-position, to the corresponding signals of $1 \mathfrak{a}, \mathrm{b}, 2 \mathrm{a}, \mathrm{b}$, and $3 a, b$, respectively.

In conclusion, we have achieved the synthesis of three tricyclic models $(\mathbb{1 c}),(2 \mathfrak{c})$, and (3c) for the heterocyclic portions of the marine sponge alkaloids asmarines A-F. The correctness of the structures proposed for the heterocyclic moieties in these alkaloids has been supported as a result of the present synthesis.

\section{ACKNOWLEDGEMENT}

This work was supported by a Grant-in-Aid for Scientific Research (C) (No. 12672051) from the Ministry of Education, Culture, Sports, Science and Technology, Japan. 


\section{REFERENCES AND NOTES}

1. For a review on the purine alkaloids, see: Atta-ur-Rahman and M. I. Choudhary, 'The Alkaloids,' Vol. 38, ed. by A. Brossi, Academic Press, New York, 1990, pp. 225-323.

2. (a) T. Yosief, A. Rudi, Z. Stein, I. Goldberg, G. M. D. Gravalos, M. Schleyer, and Y. Kashman, Tetrahedron Lett., 1998, 39, 3323; (b) T. Yosief, A. Rudi, and Y. Kashman, J. Nat. Prod., 2000, $63,299$.

3. (a) M. Ohba, N. Kawase, T. Fujii, K. Aoe, K. Okamura, R. Fathi-Afshar, and T. M. Allen, Tetrahedron Lett., 1995, 36, 6101; (b) M. Ohba, N. Kawase, and T. Fujii, Heterocycles, 1995, 41, 2661; (c) M. Ohba, N. Kawase, and T. Fujii, J. Am. Chem. Soc., 1996, 118, 8250; (d) M. Ohba, K. Iizuka, H. Ishibashi, and T. Fujii, Tetrahedron, 1997, 53, 16977.

4. D. Pappo, A. Rudi, and Y. Kashman, Tetrahedron Lett., 2001, 42, 5941.

5. It is known that amination of 6-chloro-9-(2-tetrahydropyranyl)purine with $\alpha, \alpha$-dimethylallylamine, a sterically congested amine possessing an adjacent quarternary carbon like asmarines, provides 6-( $\alpha, \alpha-$ dimethylallylamino-9-(2-tetrahydropyranyl)purine. ${ }^{13}$

6. (a) J. A. Montgomery and C. Temple, Jr., J. Am. Chem. Soc., 1961, 83, 630; (b) G. B. Elion, J. Org. Chem., 1962, 27, 2478; (c) H. J. Schaeffer and R. Vince, J. Med. Chem., 1965, 8, 33; (d) T. C. McKenzie and J. W. Epstein, J. Org. Chem., 1982, 47, 4881; (e) J. L. Kelley, M. P. Krochmal, J. A. Linn, E. W. McLean, and F. E. Soroko, J. Med. Chem., 1988, 31, 606; (f) L.-L. Gundersen, A. K. Bakkestuen, A. J. Aasen, H. Øverås, and F. Rise, Tetrahedron, 1994, 50, 9743.

7. (a) W. A. Szarek, C. Depew, H. C. Jarrell, and J. K. N. Jones, J. Chem. Soc., Chem. Commun., 1975, 648; (b) M. Iwakawa, B. M. Pinto, and W. A. Szarek, Can. J. Chem., 1978, 56, 326; (c) A. Toyota, N. Katagiri, and C. Kaneko, Chem. Pharm. Bull., 1992, 40, 1039; (d) S. Kozai and T. Maruyama, Chem. Pharm. Bull., 1999, 47, 574.

8. J. A. Montgomery and K. Hewson, J. Org. Chem., 1961, 26, 4469.

9. P. D. Jeffrey and S. W. McCombie, J. Org. Chem., 1982, 47, 587.

10. The elemental analysis pointed to the formula $\mathrm{C}_{8} \mathrm{H}_{9} \mathrm{~N}_{5} \mathrm{O} \cdot 1 / 2 \mathrm{H}_{2} \mathrm{O}$.

11. N. J. Kos, H. C. van der Plas, and W. J. F. Blees, J. Org. Chem., 1983, 48, 850.

12. 6-Chloro-7,9-dihydro-9-methyl-8H-purin-8-one (13) was prepared from 5-amino-4-chloro-6-(methylamino)pyrimidine in $80 \%$ yield according to the literature procedure ${ }^{11}$ but with some modification (urea, DMF, reflux, $4 \mathrm{~h}$ ).

13. F. Skoog, H. Q. Hamzi, A. M. Szweykowska, N. J. Leonard, K. L. Carraway, T. Fujii, J. P. Helgeson, and R. N. Loeppky, Phytochemistry, 1967, 6, 1169. 